\title{
Differences in Mathematics Learning Outcomes in Terms of Level of Motivation and Learning Styles of Students Class XI SMK Kesehatah Imelda Ritonga
}

\author{
Dede Irawan ${ }^{1}$, Amin Harahap ${ }^{2}$ \\ ${ }^{1,2}$ Faculty of Teacher Training and Education, Universitas Labuhanbatu, Indonesia \\ aminharahap19@gmail.com,idede0602@gmail.com
}

\begin{abstract}
This study aims to determine differences in mathematics learning outcomes of students in terms of level of motivation learning styles of students and How students ' mathematics learning Outcomes in terms of level of motivation and learning styles of students. This research experiments. The research Data consists of the initial test and final test about the material that has been delivered using the approach of learning motivation and learning styles with the dependent variable is learning outcomes. In this study, the researchers obtained data from the results of pre-test and post-test conducted in the experimental class(the class that viewed from learning motivation) and class control(class in terms of learning styles). Based on the above analysis, it has been proven that there are significant differences between the learning outcomes in terms of learning motivation and learning styles in enhancing student learning outcomes in Mathematics learning in the SMK Kesehatan Imelda Ritonga.
\end{abstract}

Keywords motivation to learn; learning style; learning outcomes

\section{Introduction}

The result of learning is a change in behavior acquired after experiencing the learning activities. The acquisition aspects of the behavior changes depending on what is learned by learner (Anni, 2004: 4). In learning a change in behavior that must be achieved by students after carrying out the learning activities defined in the learning objectives. In the process of learning, the study is important because it can be a clue to determine the extent to which the success of students in learning activities that have been done. The results of the study can be known through evaluation to measure and assess whether students have mastered the knowledge learned over the guidance of the teacher in accordance with the objectives formulated. The results of the study according to Sudjana (2004:49) will appear in the change of behavior, technically formulated in a statement of verbal through the goal of teaching. In other words, the formulation of teaching objectives contains learning outcomes that are expected mastered the students, which includes three aspects, cognitive, affective, psychomotor. The learning process is very important in the teaching and learning activities, where the learning process is related for the achievement of change. Other factors that affect student learning outcomes is the learning style. Learning style James and Gardner (in Ghufron and Risnawita 2014: 42) is the complex ways in which the students perceive and feel the most effective and efficient in process, store and recall what they have learned. Students will more easily undergo the teachinglearning activities if it can utilize the learning styles possessed by individual students. Learning is no longer boring and make students become not passionate in following the 
lessons in the school. Utilization of student learning styles is closely related to the learning outcomes.

The results of good learning will not be difficult to achieve if the student is able to utilize the learning style that it has to be maximized in the activities of learning, both at school and at home. Things become problems is the utilization of learning styles by each student is different, there are able to maximize the learning style he has and no one yet can take advantage of learning styles it has to the maximum. In general, the learning difficulties experienced by students caused by the influence of learning motivation and learning style are different. Students who have learning motivation high will be enterprising and diligent in undergoing their studies so that learning outcomes will be optimal, while students who have low motivation will tend to become lazy in learning so that learning outcomes not optimal. Students who are able to utilize the learning style that they get with the good then the students will feel happy in learning because they feel unable to follow lessons, whereas students who are less able to utilize their learning style to better the student will feel bored and not passionate in learning. Therefore, it would be useful if students have learning motivation high and supported with utilization of the learning styles that is the maximum possessed by each student, so that learning outcomes obtained were better and the maximum. After researchers conducted observations in VOCATIONAL Health Imelda Ritonga, found the problem of the low student learning outcomes, the Low learning outcomes in mathematics due to several things, among them lies in the style and learning motivation of students.

\section{Review of Literatures}

\subsection{Understanding of Learning Outcomes}

Al-Nawawi (2007) in Susanto (2015: 5) states learning can be interpreted as the level of success of students in learning subject matter in schools that is expressed in scores obtained from the test results about a specific subject matter. Winkel (1996), Purwanto (2014: 45) describes the results of learning is a change resulting in a human change in attitude and behavior. Meanwhile, according to rifa'i and Anni (2012: 69) the result of learning is a change in behavior obtained by the students after experiencing the learning activities. The results of the study is the culmination of a process that has been done in learning (Anitah et al, 2009: 2.19). Learning outcomes should show a change of behavior of new students.

\subsection{Learning Style}

Learning style can be easily described as how people understand and remember information. James and Gardner (in Ghufron and Risnawita 2014: 42) argues that learning style is a complex way where the students perceive and feel the most effective and efficient in process, store and recall what they have learned. Merriam and Caffarella (in Ghufron and Risnawita, 2014: 42) also defines learning style is characteristic of individuals about how to process information, feel, and act in the situation-learning situation. In line with Merriam and Caffarella, Kolb (in Ghufron and Risnawita 2014: 42) says that learning style is a method of an owned individual to get the information, so that in principle the learning style is an integral part in the cycle of active learning. Based on the understanding of learning styles according to experts, it can be concluded that learning style is the way to be taken by each person in possession of the information they receive. Learning styles are individual for each person. So in general, learning style is assumed to refer to the personality, beliefs, choices and behaviors used by individuals to help their learning in a situation that has been conditioned. 


\subsection{Motivation to Learn}

The motivation comes from the word "movere" which means to push, drive power or force that causes an action or deed. Sardiman (2014:73) argues that the motivation originated from the word "motive", motivation can be defined as the driving force that has become active. Motives to be active at certain moments, especially when the need to reach a destination is perceived or urgent. The Motif can be regarded as the driving force of the in and in in the subject to do certain activities in order to achieve a goal. Even a motive can be defined as a condition of the internal (preparedness). Hamalik (in Suyono and Hariyanto 2015: 184) describes motivation is the energy change within the person characterized by the onset of feelings and reactions to achieve the goal. Motivation can also be defined as a series of businesses to provide certain conditions, so that a willing and want to do something. Meanwhile, Donald (in Sardiman 2014: 73) argues that in motivation there are three important elements, namely: (1) that the motivation to initiate the occurrence of the change of energy in every human individual.

The development of motivation will bring some energy change in the system of the "neurophysiological" that exist in the human organism. Because it involves changes in human energy (although that motivation comes from within man), appearances will be related to the physical activities of man; (2) motivation is characterized by the appearance of/ the "feeling" of a person. In this case the motivation is relevant to the issues of the psychology and emotions that can determine human behavior; (3) motivation will be stimulated because of the purpose. So in this case the motivation is the response of an action, namely goal. Saragih and Ananda (2019) stated that motivation is a process in a person to stimulate behavior and channel it in ways that provide benefits to the organization as a whole. The notion that was introduced by Lunenberg and Ornstein is an understanding that leads to motivation that is in a person when in an organization, as an employee/ labor. Motivation is indeed emerging from within man, but his appearance because they were encouraged by the presence of other elements, namely the objective concerning the about the need. Motivation can also be said of a series of businesses to provide certain conditions, so a person want to and want to do something, and if he doesn't like, then he will seek to nullify or circumvent the feelings are not like that (Sardiman,2014:75)

\section{Research Methods}

This type of research is quasi-experimental research(Quast Experiment) about differences in Mathematics learning outcomes in terms of Level of Motivation and Learning Style. Samples taken in this study consisted of two experimental groups so that each class is given the same treatment just different on the methods taught.

Table 1. Research Design

\begin{tabular}{|l|l|l|l|}
\hline Sample & Pre - test & Treatment & Post - test \\
\hline Experiments 1 & $\mathrm{T}_{1}$ & $\mathrm{X}_{1}$ & $\mathrm{~T}_{2}$ \\
\hline Experiments 2 & $\mathrm{T}_{1}$ & $\mathrm{X}_{2}$ & $\mathrm{~T}_{2}$ \\
\hline
\end{tabular}

Information:

$\mathrm{T}_{1}$ : Pre-test

$\mathrm{T}_{2}:$ Post-test

$\mathrm{X}_{1}$ : The treatment is given on the class of experiment 1 in terms of Level of Motivation

$\mathrm{X}_{2}$ : Treatment is given to the experimental class 2 in terms of Learning Styles. 
The independent variable is the variable that causes or influences, i.e. factors that are measured, manipulated or selected by the researcher to determine the relationship between the phenomena observed or observed.That includes the independent variable here is the Level of Motivation as a (X1). While the (X2) is a Learning Style. The dependent variable is the factors that diobservasikan and measured to determine the influence of the independent variables, i.e. factors that appeared, or not appeared, or changed in accordance with the introduced researchers. The dependent Variable (Y): is the result of learning.

\subsection{Data Analysis Techniques}

The steps in data analysis techniques is:

Determine the average value and the standard deviation.

a. To determine the average value of used the formula (Sudjana, 2012:67), namely:

$$
X=\frac{2 x}{n}
$$

b. To calculate the standard deviation (s) used formula (Sudjana, 2012:94), namely:

$$
S D=\sqrt{\frac{n \sum x_{1^{2}}-\left(\sum x_{1}\right)}{n(n-1)}}
$$

Test the requirements of the statistics used as the basis in hypothesis testing, among other tests of normality and homogeneity of variance, Then perform the ANOVA test and $t$ test.

\section{Results and Discussion}

Test prerequisite analysis is done before performing data analysis. Preconditions used in this research is normality test and homogeneity test. The results of the test a prerequisite of the analysis is presented as follows:

1. Normality test of the experimental class

1) The Variable Y(The Results Of Learning Experiments),K-S=1,204; $\mathrm{P}=0,110$ ( $\mathrm{P}>$ $0,05)$, then the Normal distribution

2) The Variable $X$ (Motivation To Learn Experiment), $K-S=0,901 ; P=0,392(P>0,05)$, then the Normal distribution

3) The Variable X1(The Learning Style Of The Experimental), K-S=0,961; $\mathrm{P}=0,315$ $(\mathrm{P}>0,05)$, then the Normal distribution.

2. Normality test class control

1) The Variable $\mathrm{Y}$ (The Result Of Learning Control), $\mathrm{K}-\mathrm{S}=1,224 ; \mathrm{P}=0,100(\mathrm{P}>0,05)$, then the Normal distribution

2) The Variable $\mathrm{X}$ (Motivation To Learn Control), $\mathrm{K}-\mathrm{S}=0,850 ; \mathrm{P}=0,465(\mathrm{P}>0,05)$, then the Normal distribution

3) The Variable X1(The Learning Style Of The Control), K-S=0,812; P=0,524 (P > $0,05)$, then the Normal distribution

The results of significance for "Asymp.Sig. (2-tailled)" everything is greater than 0.05 , then the distribution of the data has been normal.

3. Homogeneity test of the experimental class

Having known the level of normality of the data, then further test the homogeneity. 
Table 2. Test of Homogeneity of Variances Learning Outcomes

\begin{tabular}{|c|c|c|c|}
\hline Levene Statistic & $\overline{d f 1}$ & $\overline{d f 2}$ & Sig. \\
\hline .000 & 1 & 62 & .985 \\
\hline
\end{tabular}

Table 3. ANOVA

Learning Outcomes

\begin{tabular}{|l|r|r|r|r|r|}
\hline & Sum of Squares & df & Mean Square & F & \multicolumn{1}{c|}{ Sig. } \\
\hline Between Groups & 749.391 & 1 & 749.391 & 96.828 & .000 \\
Within Groups & 479.844 & 62 & 7.739 & & \\
Total & 1229.234 & 63 & & & \\
\hline
\end{tabular}

4. Homogeneity test of the experimental class and the control class.

From the table test of Homogeneity of the experimental class and class control can be summarized as follows :

Table 4. Conclusion test of homogeneity

\begin{tabular}{|l|l|l|l|}
\hline \multicolumn{1}{|c|}{ Class } & \multicolumn{1}{c|}{$F_{\text {count }}$} & \multicolumn{1}{c|}{ sig } & Keterangan \\
\hline Experiments & 96.828 & 0.985 & Homogeneous \\
\hline Control & 18.056 & .0 .743 & Homogeneous \\
\hline
\end{tabular}

The results of the homogeneity test of research variables note the value of $\mathrm{F}$ calculate the experimental class 96.828 with a significant value of 0,985 while the calculated F-class control 18.056 with significant 0,743 . From the results of the calculation of the significant data of the experimental class nor the control class is larger than 0.05 ( $\operatorname{sig}>0,05)$, it can be concluded that the data in this study has a variance that is homogeneous

1. The $t$ test of the experimental Class Learning Outcomes in terms of Motivation and Learning Style.

Table 5. Output "Independent sampel T Test"

\begin{tabular}{|c|c|c|c|c|c|c|c|c|c|c|}
\hline \multicolumn{11}{|c|}{ Independent Samples Test } \\
\hline & & \multicolumn{2}{|c|}{$\begin{array}{c}\text { Levene's Test for Equality of } \\
\text { Yariances }\end{array}$} & \multicolumn{7}{|c|}{ Etest for Equalihy of Means } \\
\hline & & \multirow[b]{2}{*}{$\mathrm{F}$} & \multirow[b]{2}{*}{ Sin. } & \multirow[b]{2}{*}{$\mathrm{i}$} & \multirow[b]{2}{*}{ dif } & \multirow[b]{2}{*}{ Sir. (2-tailed) } & \multirow[b]{2}{*}{$\begin{array}{c}\text { Mean } \\
\text { Difference } \\
\end{array}$} & \multirow[b]{2}{*}{$\begin{array}{l}\text { Str. Emor } \\
\text { Difference }\end{array}$} & \multicolumn{2}{|c|}{$\begin{array}{c}95 \% \text { Confidence Interval of the } \\
\text { Diference }\end{array}$} \\
\hline & & & & & & & & & Lower & Upper \\
\hline Hasil Belajar & $\begin{array}{l}\text { Equal variances } \\
\text { assumed }\end{array}$ & .000 & 985 & 9.840 & 62 & .000 & 6.844 & .695 & 5.453 & 8.234 \\
\hline & $\begin{array}{l}\text { Equal variances not } \\
\text { assumed }\end{array}$ & & & 9.840 & 61.689 & .000 & 6.844 & .695 & 5.453 & 8.234 \\
\hline
\end{tabular}

Based on the output of the above unknown value sig. "levene's Test for Equaliti of Variances" is equal to $0.985>0.005$, it means that the variance of the data between the motivation to learn with learning styles is homogeneous or the same. So the interpretation of the output table above is based on the value contained in the "Equal variaces assumed"

Based on the tebel Independent samples $T$ Test in the section on "Equal variaces assumed" known value sig.(2-tailed) of $0.000<0.05$, then as the basis of decision-making in a test of the Independent samples T-Test that $\mathrm{HO}$ is rejected and Ha accepted. Thus it can 
be concluded there are differences in learning outcomes in terms of motivation to learn with learning styles. Furthermore, from the table output of the above unknown value of the "Mean difference" is 6.844. this value shows the difference between the average results of student learning on the learning motivation with the average of learning outcomes on the learning style i.e. $80.81-73.97=6.84$ and the difference the difference is 5.453 until 8.234 ( $95 \%$ confidence interval of the difference).

2. The $t$ test of the experimental Class Learning Outcomes in terms of Motivation and Control Classes in terms of Learning Styles.

The analysis of independent-Sample t-test to the experimental class learning motivation and class control style study aims to determine whether there is significant difference in the experimental class and the control class. The conclusions of the study stated significant if the $t$ count $>t$ table at significance level of $5 \%$ and a value of $p<0.05$.

Table 6. Output "Independent sampel T Test"

\begin{tabular}{|c|c|c|c|c|c|c|c|c|c|c|}
\hline \multicolumn{11}{|c|}{ Independent Samples Test } \\
\hline & & \multicolumn{2}{|c|}{$\begin{array}{c}\text { Levene's Test for Equality of } \\
\text { Yariances }\end{array}$} & \multicolumn{7}{|c|}{ ttest for Equaily of Means } \\
\hline & & \multirow[b]{2}{*}{$\mathrm{F}$} & \multirow[b]{2}{*}{$\mathrm{sid}$} & \multirow[b]{2}{*}{$t$} & \multirow[b]{2}{*}{$\mathrm{df}$} & \multirow[b]{2}{*}{ Sid (2tailed) } & \multirow[b]{2}{*}{$\begin{array}{c}\text { Mean } \\
\text { Difference } \\
\end{array}$} & \multirow[b]{2}{*}{$\begin{array}{l}\text { Stid Enor } \\
\text { Offenence }\end{array}$} & \multicolumn{2}{|c|}{$\begin{array}{l}95 \% \text { Confidence Irterval of the } \\
\text { Diference }\end{array}$} \\
\hline & & & & & & & & & Lower & Uboer \\
\hline \multirow[t]{2}{*}{ Hasil Belajar } & $\begin{array}{l}\text { Equal variances } \\
\text { assumed }\end{array}$ & .009 & .927 & 8.772 & 64 & .000 & 5.910 & .674 & 4564 & 7.256 \\
\hline & $\begin{array}{l}\text { Equal variances not } \\
\text { assumed }\end{array}$ & & & 8.744 & 62.294 & .000 & 5.910 & .676 & 4.559 & 7.261 \\
\hline
\end{tabular}

Based on the output of the above unknown value sig. "levene's Test for Equaliti of Variances" is equal to $0.927>0.005$, it means that the variance of the data between the motivation to learn with learning styles is homogeneous or the same. So the interpretation of the output table above is based on the value contained in the "Equal variaces assumed"

Based on the tebel Independent samples $T$ Test in the section on "Equal variaces assumed" known value sig.(2-tailed) of $0.000<0.05$, then as the basis of decision-making in a test of the Independent samples T-Test that $\mathrm{HO}$ is rejected and Ha accepted. Thus it can be concluded there are differences in learning outcomes in terms of motivation to learn with learning styles. Furthermore, from the table output of the above unknown value of the "Mean difference" is 5.910. this value shows the difference between the average results of student learning on the learning motivation with the average results of the study on learning styles namely $73.97-68.06=5.91$ and the difference the difference is 4.564 until 7.256 (95\% confidence interval of the difference)

3. The t test Learning Outcomes experimental class and class control.

The analysis of independent-Sample t-test against the learning outcomes experimental class and the results of the study aimed to determine whether there is significant difference in the class learning outcomes experimental class and the learning outcomes of control class. The conclusions of the study stated significant if the $t$ count $>t$ table at significance level of $5 \%$ and a value of $p<0.05$ 
Table 7. Independent sampel T Test

\begin{tabular}{|c|c|c|c|c|c|c|c|c|c|c|}
\hline \multicolumn{11}{|c|}{ InsependertSamples Test } \\
\hline & & \multicolumn{2}{|c|}{$\begin{array}{l}\text { Levene's Testifor Equality of } \\
\text { Wariantes }\end{array}$} & \multicolumn{7}{|c|}{ Hestifor Equaly oflleans } \\
\hline & & \multirow[b]{2}{*}{$\mathrm{F}$} & \multirow[b]{2}{*}{$\sin$} & \multirow[b]{2}{*}{1} & \multirow[b]{2}{*}{ df } & \multirow[b]{2}{*}{ Sic (2taled) } & \multirow[b]{2}{*}{$\begin{array}{l}\text { Nean } \\
\text { Diference }\end{array}$} & \multirow[b]{2}{*}{$\begin{array}{l}\text { Stil Emtr } \\
\text { Diference }\end{array}$} & \multicolumn{2}{|c|}{$\begin{array}{l}\text { 95\% Counfidence interval of the } \\
\text { Diference }\end{array}$} \\
\hline & & & & & & & & & Lower & Usver \\
\hline $\begin{array}{l}\text { Hasil Belajar Els dan } \\
\text { Kort }\end{array}$ & $\begin{array}{l}\text { Equalinariantes } \\
\text { assimed }\end{array}$ & 958 & 811 & 14.477 & 64 & 000 & 9930 & 806 & 8560 & $11: 300$ \\
\hline & $\begin{array}{l}\text { Eq.alingriantes not } \\
\text { ass.med }\end{array}$ & & & 14508 & 63954 & .000 & 9930 & 884 & 8563 & 11297 \\
\hline
\end{tabular}

Based on the output of the above unknown value sig. "levene's Test for Equaliti of Variances" is equal to $0.058>0.005$, it means that the variance of the data learning outcomes of experimental class with the learning outcomes of control class is homogeneous or the same. So the interpretation of the output table above is based on the value contained in the "Equal variaces assumed"

Based on the tebel Independent samples $\mathrm{T}$ Test in the section on "Equal variaces assumed" known value sig.(2-tailed) of $0.000<0.05$, then as the basis of decision-making in a test of the Independent samples T-Test that HO is rejected and Ha accepted. Thus it can be concluded there are differences in learning outcomes experimental class with the learning outcomes of control class. Furthermore, from the table output of the above unknown value of the "Mean difference" is 9,930. this value shows the difference between the average learning outcomes of experimental class students with average learning outcomes of control class, namely $80,81-70,88=9,930$ and the difference the difference is 8.560 until 11,300 (95\% confidence interval of the difference).

\section{Conclusion}

Based on the above analysis, that there is a difference between learning outcomes in terms of learning motivation and learning styles in enhancing student learning outcomes in Mathematics learning SMK kesehatan Imelda Ritonga.

\section{References}

Abdurrahman, Mulyono. (2012). Anak Berkesulitan Belajar. Jakarta: Rineka Cipta.

Anitah, Sri, dkk. 2009. Strategi Pembelajaran di SD. Jakarta: Universita Terbuka

Anonim. 2013. Perundangan tentang Kurikulum Sistem Pendidikan Nasional2013. Yogyakarta: Penerbit Pustaka Yustisia

Arikunto, Suharsimi. 2013. Prosedur Penelitian Suatu Pendekatan Praktik. Jakarta: Rineka

Cipta. Burton, dkk. 2007. Pengembangan Pembelajaran Matematika SD. Jakarta:

Depdiknas

Ayatullah Muhammadin Al. 2015. Pengaruh Motivasi, Lingkungan, Dan Disiplin terhadap Prestasi Belajar Siswa pada Mata Pelajaran IPA KelasV SDN 19 Banda Aceh. Vol. 6 Jurnal: STKIP Bina Bangsa Getsempena

Gagne. 1989. Gaya Belajar Kajian Teoritik. Yogyakarta: Pustaka Pelajar.

Ghufron. 2014. Proses Belajar Mengajar. Jakarta: Bumi Aksara

Majid, Abdul. 2014. Strategi Pembelajaran. Bandung: Remaja Rosdakarya

Muhsetyo, Gatot, dkk. 2008. Pembelajaran Matematika SD. Jakarta: Universitas Terbuka 
Munib, Achmad, Budiyono, dan Sawa Suryana. 2012. Pengantar Ilmu Pendidikan. Semarang: UNNES Press. Poerwati, Endang. dkk. 2009. Asesmen Pembelajaran SD 3 SKS

Purwanto. 2014. Evaluasi Hasil Belajar. Yogyakarta: Pustaka Pelajar.

Saragih, S.L., and Ananda, R. (2019). The Relation between the Empowerment of Teacher's Meeting and Achievement Motivation on Teacher Performances in MTsN 3 (Islamic Junior High School 3) Simalungun. P. 115-114.

Susanto. 2015. Belajar Mudah Penelitian untuk Guru - Karyawan dan Peneliti Pemula. Bandung: Alfabeta

Siregar, Eveline dan Nara Hartini. 2010. Teori Belajar dan Pembelajaran. Bogor

Slameto. 2010. Belajar dan Faktor-faktor yang Mempengaruhi. Jakarta: Rineka Cipta

Winkel. 2004. Interaksi dan Motivasi Belajar Mengajar. Jakarta: Rajawali Pers 